\title{
SUSPENDED PARTICULATE MATTER CONCENTRATIONS RETRIEVED FROM SELF-CALIBRATED MULTISPECTRAL SATELLITE IMAGERY
}

\author{
MILAN ONDERKA ${ }^{1)}$, MAREK RODNÝ2), YVETTA VELÍSKOVÁ ${ }^{3)}$ \\ ${ }^{1)}$ Centre de Recherche Public - Gabriel Lippmann, Département Environment et Agro-biotechnologies (EVA), 41 rue du Brill, \\ L-4422 Belvaux, Luxembourg; Mailto: onderka@lippmann.lu; Tel: +352 4702 61-478 Fax: +352 470264 \\ 1),2), 3) Institute of Hydrology, SAS, Račianska 75, 83102 Bratislava, Slovakia; Mailto: veliskova@ uh.savba.sk; \\ Tel: +421 49268 (276 or 255) Fax: +421 44259404
}

Inland waters are known to be laden with high levels of suspended particulate matter (SPM). Remotely sensed data have been shown to provide a true synoptic view of SPM over vast areas. However, as to date, there is no universal technique that would be capable of retrieving SPM concentrations without a complete reliance on time-consuming and costly ground measurements or a priori knowledge of inherent optical properties of water-borne constituents. The goal of this paper is to present a novel approach making use of the synergy found between the reflectance in the visual domain $(\sim 400-700 \mathrm{~nm})$ with the near-infrared portion of the spectrum $(\sim 700-900 \mathrm{~nm})$. The paper begins with a brief discourse of how the shape and spectral dependence of reflectance is determined by high concentrations of SPM. A modeled example is presented to mimic real-world conditions in fluvial systems, with specific absorption and scattering coefficients of the virtual optically active constituents taken from the literature. Using an optical model, we show that in the visual spectral domain $(\sim 400-700 \mathrm{~nm})$ the water-leaving radiance responds to increasing SPM $\left(0-100 \mathrm{~g} \mathrm{~m}^{-3}\right)$ in a non-linear manner. Contrarily to the visual spectra, reflectance in the near infrared domain $(\sim 700-900$ $\mathrm{nm})$ appears to be almost linearly related to a broad range of SPM concentrations. To reduce the number of parameters, the reflectance function (optical model) was approximated with a previously experimentally verified exponential equation (Schiebe et al., 1992: Remote sensing of suspended sediments: the Lake Chicot, Arkansas project, Int. J. Remote Sensing, 13, 8, 1487-1509). The SPM term in Schiebe's equation was expressed as a linear function of top-of-atmosphere reflectance. This made it possible to calibrate the reflectance in the visual domain by reflectance values from the near-IR portion of the spectrum. The possibility to retrieve SPM concentrations from only remote sensing data without any auxiliary ground mea-surements is tested on a Landsat ETM + scene acquired over a reservoir with moderately turbid water with SPM concentrations between $15-70 \mathrm{~g} \mathrm{~m}^{-3}$. The retrieved concentrations (on average) differ from in-situ measurement by $\sim 10.5 \mathrm{~g} \mathrm{~m}^{-3}$.

KEY WORDS: Self-Calibration, Suspended Sediments, SPM, Saturation, Optimization.

Milan Onderka, Marek Rodný, Yvetta Velísková: STANOVENIE KONCENTRÁCIE SUSPENDOVANÝCH LÁTOK PROSTREDNÍCTVOM KALIBROVANÉHO MULTISPEKTRÁLNEHO SATELITNÉHO ZOBRAZOVANIA. J. Hydrol. Hydromech., 59, 2011, 4; 64 lit., 4 obr. 1 tab.

Ciel'om príspevku je prezentovat' alternatívne spracovanie satelitných snímok na odhad koncentrácie suspendovaných sedimentov vo vodných útvaroch. Prvá čast’ článku sa venuje teórii a fyzikálnej podstate reflektancie a vplyvu prirodzene sa vyskytujúcich opticky aktívnych prvkov vo vode (suspendované sedimenty, pigmenty a rozpustené látky) na reflektanciu snímanú prostriedkami dial'kového prieskumu Zeme. Na modelovom príklade sme ukázali, že so zvyšovaním koncentrácie suspendovaných látok dochádza k saturácii signálu reflektancie.V druhej časti príspevku sme opísali spôsob využitia nelineárnosti vzt’ahu medzi reflektanciu vo viditel'nej časti ( 400-700), a kvázi-linearitov v infračervenej časti ( 700-900 nm) elektromegnetického spektra a koncentrácie suspendovaných sedimentov. Optimalizáciou tohto nelineárneho vzt’ahu sme odhadli koncentrácie suspendovaných sedimentov pre zdrž Hrušov pri Bratislave s RMSE $10.5 \mathrm{~g} \mathrm{~m}^{-3}$.

KLUUČCOÉ SLOVÁ: samokalibrácia, suspendované sedimenty, saturácia, optimalizácia. 


\section{Introduction}

Monitoring of soil erosion and the subsequent transport of suspended sediments in fluvial systems is important for our understanding of the Earth's crust evolution (Chakrapani, 2005; Syvitski et al., 1998), siltage of waterways (Sanjay and Pratap, 2002), biogeochemical cycling of pollutants and nutrients (Viers et al., 2009; Chakrapani, 2005; Klaver et al., 2007; Karbassi and Moattar, 2006), and modeling of photosynthetically available light for submerged aquatic vegetation (Gallegos, 2001; Kelbe et al., 2005; Christian \& Sheng, 2003). At present, impacts of suspended matter carried by rivers are still poorly monitored, especially in large or remote areas. The transport of suspended matter in inland waters and estuaries is conventionally assessed from field sampling campaigns that are carried out only in sparse locations and in limited sampling intervals. The problem of poor spatial representativeness of such point measurements, inaccessibility of remote sites, and logistic issues encountered with field work, can be relieved by remote sensing. Numerous investigators report that earth-observing satellites and air-borne sensors can be used for retrieving and possibly also monitoring suspended sediments over vast areas (e.g. Doxaran et al., 2009; Wang et al., 2007; Warrick et al., 2004; Kloiber et al., 2002; Giardino et al., 2001; to cite only a few). Suspended particulate matter (SPM) in surface waters can therefore be envisioned as a natural tracer detectable by remote sensing platforms.

The scientific literature refers to two approaches that are commonly adopted in the retrieving of suspended particulate matter from remotely sensed data: (i) empirical techniques based on relating image-derived quantities (e.g. reflectance or radiance) against field measurements of SPM conducted coincidently with a satellite's overpass; and (ii) physical models based on radiation transfer modeling, also known as the "bio-optical" models (e.g. Bukata et al., 2004; Mishra 2004; Doxaran et al., 2002a, b; Dekker et al., 2001). Although empirically derived relationships between reflectance and ground-truth data are attractive in terms of their computational simplicity, a serious constraint of this approach is that field measurements of SPM are not always available with sufficient quantity and quality. A considerable amount of optical diversity has been observed among different geo- graphical regions with their intrinsic geology and land-use practices (Mélin et al., 2009; Bukata et al., 2004; Bukata et al., 1997; Decho et al., 2003). Therefore, the main limitation of all empirical models is that variations in atmospheric conditions and optical properties of water preclude their use at locations other than the site for which they were proposed. On the other hand, bio-optical models are capable of relating inherent optical properties of water coloring constituents (IOPs, i.e. absorption and backscattering coefficients) to remote sensing reflectance. These models generally require knowledge of the IOPs; which is the constraint common to all bio-optical models, since IOPs may not be a priori known (IOCCG Report, 2000; Liu et al., 2003; Ouillon et al., 2008). Regardless which method (empirical or bio-optical) is used, both are site-specific, time-dependent, in other words: "unique to each body of water" ( $\mathrm{Liu}$ et al., 2003).

The fundamental question that needs to be addressed is: "How can we tackle the problem of unavailable ground-truth data for direct image calibration or in-situ (or laboratory) measurements of inherent optical properties required by bio-optical models"? The fact that, so far, there is no generic algorithm for quantifying suspended particulates from remotely sensed data, new and innovative approaches are needed. The aim of this paper is to introduce a simplistic technique by which concentrations of suspended matter would be retrieved from multispectral sensors without ground measurements - i.e. using only image-derived information. This is achieved by making use of the nonlinearity between reflectance and SPM in the visible spectral domain $(\sim 400-700 \mathrm{~nm})$, and linearity in the near-infrared domain $(\sim 700-900 \mathrm{~nm})$. The paper begins with a brief discourse on how reflectance (remote sensing reflectance and top-ofatmosphere reflectance) is modulated by the presence of various water-borne substances (colored dissolved organic matter-CDOM; suspended particulate matter - SPM; and chlorphyll-a), and water itself. This relationship is then approximated with a simplified function introduced by Schiebe et al. (1992) to reduce the number of parameters. The principles of the technique and the effect of signal saturation in the visible domain are explained first with an example using a Landsat ETM+ scene acquired over a moderately sediment-laden reservoir. 


\section{Data and methodology}

The signal recorded by a remote spectral sensor (a satellite sensor) is recorded at discrete levels referred to as "digital numbers" - DNs. To obtain physically meaningful quantities, digital numbers have to be converted into top-of-atmosphere radiance $L_{T O A}(\lambda)$. A typical equation (indicated for Landsat platform; NASA Landsat handbook) used for this procedure is:

$$
L_{T O A}(\lambda)=D N_{i} \times \text { Gain }+ \text { Offset }
$$

where $L_{T O A}(\lambda)$ is the total radiance recorded by the satellite sensor in a given spectral band $\left[\mathrm{mW} \mathrm{cm}^{-2}\right.$ $\left.\mathrm{sr}^{-1} \mu \mathrm{m}^{-1}\right], D N(\lambda)$ - the digital number in the given spectral band (dimensionless); Gain and Offset are constants specific for the used sensor. To account for the variability in exo-atmopheric irradiance, $L_{T O A}(\lambda)$ is converted to the top of atmosphere reflectance $R_{T O A}(\lambda)$ as:

$$
R_{T O A}(\lambda)=\frac{\pi L_{T O A}(\lambda)}{E_{\text {exO }} d \cos \theta},
$$

where $E_{\text {exo }}$ is the exoatmospheric solar irradiance $\left[\mathrm{mW} \mathrm{cm}^{-2} \mu \mathrm{m}^{-1}\right], d$ - the Sun-Earth distance (in astronomical units) calculated for the data of image, and $\theta$ is the solar zenith angle. The top-ofatmosphere reflectance $R_{T O A}(\lambda)$ can be partitioned into its individual components (Gordon and Wang, 1994) as:

$$
\begin{aligned}
& R_{T O A}(\lambda)=\underbrace{R_{R}(\lambda)+R_{M}(\lambda)+R_{\text {refl }}(\lambda)}_{R^{*}(\lambda)}+ \\
& +t(\lambda) R_{r S}(\lambda)
\end{aligned}
$$

where $R_{T O A}(\lambda)$ is the top-of-atmosphere reflectance (dimensionless) for a given wavelength (or $i$-th spectral band of a satellite sensor); the collective term $\left[R_{R}(\lambda)+R_{M}(\lambda)+R_{\text {refl }}(\lambda)\right]$ is the reflectance produced by the atmosphere resulting from Rayleigh and Mie scattering on gas molecules and aerosols and reflection from the air-water interface [collectively denoted as $R^{*}(\lambda)$ ]; and $R_{r s}(\lambda)$ - the remote sensing reflectance; and $t(\lambda)$ is the diffuse transmittance of the atmosphere.

Optical theory shows (Morel and Gentili, 1993; Gordon et al., 1988) that $R_{r s}$ is directly related to irradiance reflectance $R(0-)$ through a corrective term accounting for the refraction and reflection phenomena of the air-water interface:

$$
R_{r s} \approx \frac{(1-\rho)(1-\bar{\rho})}{n^{2}(1-\bar{r} R(0-))} \frac{R(0-)}{Q},
$$

where $n$ is the refractive index of water $(=1.34) ; \rho$ - the internal Fresnel reflectance $(=0.021) ; \bar{\rho}-$ the air-water Fresnel reflection at the interface $(\sim$ $0.04) . \bar{r}$ - the water-air reflection $(=0.48) ; Q\left(\mathrm{~s} \mathrm{r}^{-1}\right)$ - a geometric parameter accounting for bidirectional effects (Morel and Gentili, 1996) defined as the ratio of the upwelling irradiance to downwelling radiance, and takes values between 3.1 and 5.6. The irradiance reflectance $R(0-)$ is a function of the total absorption coefficient $a(\lambda)$ and backscattering coefficient $b_{b}(\lambda)$ for a given wavelength (Gordon et al., 1988):

$R(0-)=f \frac{b_{b}(\lambda)}{a+b_{b}(\lambda)}$,

where $f$ is a coefficient primarily depending on illumination geometry $(\sim 0.33$ for the Sun at zenith and for various types of waters, Morel and Prieur, 1977).

\section{Inherent optical properties}

Total inherent optical properties of a water body (IOPs) can be expressed as a linear combination of IOPs characterizing each of the optically active constituents:

$$
\begin{aligned}
& a(\lambda)=a_{w}(\lambda)+a_{N A P}(\lambda)+a_{C D O M}(\lambda)+a_{p h}(\lambda), \\
& b_{b}(\lambda)=b_{b w}(\lambda)+b_{b N A P}(\lambda)+b_{b p h}(\lambda)
\end{aligned}
$$

where subscripts $w, \mathrm{CDOM}, p h$, and NAP, denote water, yellow substances (colored dissolved organic matter), phytoplankton, and non-algal particles, respectively.

Absorption by chemically pure water $\left(a_{w}\right)$ increases with wavelength (for tabulated continuous Vis-NIR spectra see e.g. Pope and Fry, 1997; Smith and Baker, 1981; Morel, 1974). Absorption by colored dissolved organic matter (CDOM) exponentially decreases with wavelength. Bricaurd et al., (1981) investigated several rivers differing in the content and origin of CDOM. Their study revealed 
that absorption by dissolved substances can be realistically expressed as:

$$
\begin{aligned}
& a_{\text {CDOM }}(\lambda)=c_{\text {CDOM }}(440) \\
& \exp \left(-s_{\text {CDOM }}(\lambda-440)\right),
\end{aligned}
$$

where $a_{C D O M}(440)$ is absorption $\left[\mathrm{m}^{-1}\right]$ by CDOM at the reference wavelength of $440 \mathrm{~nm}$, and $s_{C D O M}$ is the spectral slope coefficient $\left[\mathrm{nm}^{-1}\right]$. Experimental work has revealed that the slope $s_{C D O M}$ varies between $0.01-0.03 \mathrm{~nm}^{-1}$, and a mean value of 0.015 $\mathrm{nm}^{-1}$ can be taken representative of a variety of waters (Binding et al., 2005; Jerlov, 1968; Kirk, 1976; Bricaurd et al., 1981). For illustration, in oceanic waters and oligotrophic waters $a_{\text {СDOM }}(440)$ may be well below $0.15 \mathrm{~m}^{-1}$; while in coastal and inland waters $a_{C D O M}(440)$ usually exerts higher values.

Absorption by suspended non-algal particles (NAP) decreases with increasing wavelength. Bowers and Binding (2006) proposed the following relationship for calculation of the absorption by NAP:

$$
a_{N A P}(\lambda)=a_{N A P}^{*}(440) \exp \left(-s_{N A P}(\lambda-440)\right),
$$

where $s_{N A P}$ is the slope coefficient $\left[\mathrm{nm}^{-1}\right]$, $a_{N A P}^{*}(440)$ is the specific absorption coefficient measured at the reference wavelength of $440 \mathrm{~nm}$, mean values of $s_{N A P}$ are around $0.012 \mathrm{~nm}^{-1}$.

Absorption by phytoplankton $a_{p h}(\lambda)$ cannot be expressed analytically for the entire vis-NIR region; but its spectral dependency can be inferred from either tabulated values or from graphical presentations. For the subsequent simulations, we used the absorption and backscattering spectra for phytoplankton reported by Lahet et al. (2000). $a_{p h}(\lambda)$ and $b_{b p h}(\lambda)$ were calculated for chlorophyll-a concentrations of $10 \mathrm{mg} \mathrm{m}^{-3}$.

Scattering by particulate matter (non-algal NAP) can be conveniently expressed as scattering per unit concentration $-\mathrm{b}_{\mathrm{NAP}}^{*}(\lambda)\left[\mathrm{m}^{2} \mathrm{~g}^{-1}\right]$, which is known as the mass specific scattering coefficient. The spectral dependency of particulate scattering can be written as:

$$
b_{N A P}(\lambda)=N A P \times b_{N A P}^{*}(555)\left(\frac{\lambda}{555}\right)^{n} \text {, }
$$

where the exponent may vary between 1 and 2 (Gallegos et al., 2005), and depends on the particle size distribution, density and refractive index of suspended particulates. The mass specific scattering coefficient of NAP varies geographically; e.g. in the Thames estuary $b^{*}{ }_{\mathrm{NAP}}(\lambda)=0.22 \mathrm{~m}^{2} \mathrm{~g}^{-1}$, and 0.56 $\mathrm{m}^{2} \mathrm{~g}^{-1}$ along the Alaskan coast (Babin, 2003). The value of $b^{*}{ }_{\text {NAP }}$ is determined by the granulometric composition, particle density, refractive index and the ratio of the mineral and non-mineral components (Bowers et al., 2009). For the subsequent simulations, we used a mean value of $0.5 \mathrm{~m}^{2} \mathrm{~g}^{-1}$ to represent a realistic situation in in-land Case-II waters. Because Eq. (7) requires knowledge on the backscattering coefficients rather then scattering coefficients, the scattering coefficients must be corrected by the Petzold (1972) scattering phase function, which was experimentally defined as the ratio of $b(\lambda) / b_{b}(\lambda)=0.019$ in turbid waters of San Diego Harbor, CA, USA. Since scattering on water molecules is isotropic, the backscattering coefficient of water $b_{b w}(\lambda)$ is assumed to be equal to onehalf of the total scattering coefficient $b_{w}(\lambda)$ of pure water. Values of $b_{w}(\lambda)$ were taken from Smith and Baker (1981).

\section{The shape of remote sensing reflectance}

The foregoing simulation of remote sensing reflectance $R_{r s}$ is intended only to illustrate its shape across the visible and near-infrared spectral domains. An example generated from synthetic data is simulated for 500-900 $\mathrm{nm}$. The absorption and scattering coefficients of the individual coloring components were adopted from the literature. SPM is allowed to increase from 0 to $100 \mathrm{~g} \mathrm{~m}^{-3}$. Magnitudes of the absorption and scattering coefficients were chosen to mimic a realistic situation in inland mesotrophic waters, i.e. $a_{C D O M}(440)$ was set to 0.5 $\mathrm{m}^{-1}$ and $b_{N A P}{ }_{N A}=0.5 \mathrm{~m}^{2} \mathrm{~g}^{-1}$. Eq. (4) and Eq. (5) was used to calculate $R_{r s}$, with total backscattering and absorption coefficients calculated according Eq. (6) through Eq. (10). The Sun is assumed to be at zenith, and the geometric and illumination parameters in Eq. (4) are set as follows: $Q=3.1 ; f=0.33$; $\frac{(1-\rho)(1-\bar{\rho})}{n^{2}} \approx 0.54$, (Doxaran et al., 2002a, b).

As concentrations of SPM increase, $R_{r s}$ increases non-linearly in the visual domain (Fig. 1; 500 and $600 \mathrm{~nm})$. At longer wavelengths $(850 \mathrm{~nm}$ is shown), $R_{r s}$ responds to increasing SPM in almost a perfectly linear manner. The wavelength dependency of $R_{r s}$ appears to be pronounced in shorter wavelengths, where $R_{r s}$ tends to flatten out at elevated concentrations of SPM. This effect has been reported in a number of studies, and is often referred to as 
asymptotic "saturation" (Dekker et al., 2011; Doxaran et al., 2002a, b; Doxaran et al., 2004; Han et al., 1996; Schiebe et al., 1992). Therefore, in highly turbid waters the recorded signal may be relatively insensitive to small changes in SPM above a certain limit (depending on the backscattering coefficient of suspended matter). By contrast, longer wavelengths $(>700 \mathrm{~nm})$ appear to be almost linear as shown in Fig. 1b). The near-infrared region of wavelengths $(\sim 700-900 \mathrm{~nm})$ is therefore deemed as the most suitable option for remote sensing over turbid waters due to its almost linear response to SPM and minimum reflectance produced from water and CDOM (Mishra, 2004; Dekker et al., 2001; Shalles et al., 2001; Talk et al., 2000; Han et al. 1996).

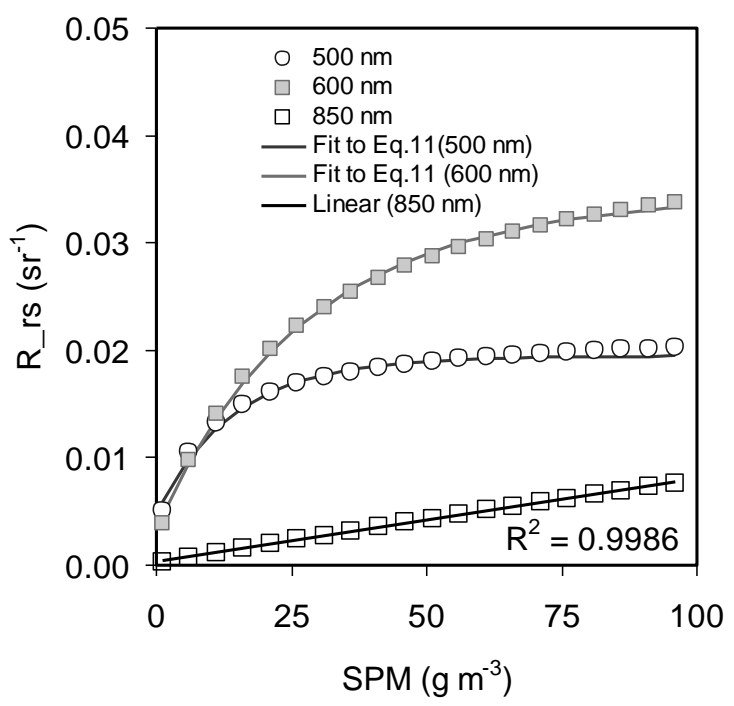

Fig. 1. Response of remote sensing reflectance $R_{r s}$ to increasing concentrations of SPM $\left(\mathrm{g} \mathrm{m}^{-3}\right)$ for three wavelengths: $500 \mathrm{~nm}$ (blue circles), $600 \mathrm{~nm}$ (yellow rectangles), and $850 \mathrm{~nm}$ (black rectangles), calculated from Eq. (4). Inherent optical properties were set as: $\mathrm{a}_{\text {CDOM }}(440)=0.5 \mathrm{~m}^{-1} ; \mathrm{b}_{\text {NAP }}^{*}=0.5 \mathrm{~m}^{2} \mathrm{~g}^{-1}$; absorption and backscattering coefficients of phytoplankton were taken from Lahet (2000). Approximation of the $R_{r s}$ was done by Eq. (11).
Approximation of the remote sensing reflectance $R_{r s}(\lambda)$

It is obvious that the determination of the spectral shape would require knowledge on the inherent optical properties of water; which are a priori unknown. For this reason Eq. (3)-(4) can not be inversely solved to retrieve SPM from remotely sensed reflectance. To achieve a reduction in the number of parameters, in the subsequent analyses we will use a simplified empirical model devised by Schiebe et al. (1992) to approximate Eq. (4):

$$
R_{r S}(\lambda)=B(\lambda)\left[1-\exp \left(-\frac{S P M}{S(\lambda)}\right)\right]
$$

where $R_{r s}(\lambda)$ is the remote sensing reflectance, $B(\lambda)$ - the asymptotic value of $R_{r s}(\lambda), S P M$ - the concentration of suspended sediments $\left[\mathrm{g} \mathrm{m}^{-3}\right], S(\lambda)-$ the saturation concentration of SPM for a given wavelength $\left[\mathrm{g} \mathrm{m}^{-3}\right]$.

The asymptotic value $B(\lambda)$ is the reflectance that would be theoretically produced under conditions of extremely high levels of SPM. The "saturation concentration" - $S(\lambda)$ can be understood as a concentration at which the produced reflectance is approximately $1-\mathrm{e}^{-1}$ or approximately $63 \%$ of the asymptotic value $-B(\lambda)$.

From the above discourse and the simulation of $R_{r s}(\lambda)$ for the near-IR domain (Fig. 1) we can consider the relationship between $R_{r s}(\lambda)$ and SPM as linear. It should be noted here that our simulation of remote sensing reflectance $R_{r s}(\lambda)$ presented in Fig. 1 was made for "known" concentrations of SPM and IOPs of all constituents. Nevertheless, the fact that $R_{T O A}(\lambda)$ can replace $R_{r s}(\lambda)$ is obvious from Eq. (3) according to which $R_{T O A}(\lambda)$ increases with $R_{r s}(\lambda)$ linearly, and hence for the near-IR domain SPM can be expressed as a function of $R_{T O A}(\lambda)$ :

$$
S P M=\alpha(\lambda)+\beta(\lambda) \times R_{T O A}(\lambda),
$$

where $R_{T O A}(\lambda)$ is the top-of-atmosphere reflectance in the near-IR portion of the spectrum; $\alpha(\lambda), \beta(\lambda)$ are optimized parameters (see the text below).

Then, combing Eq. (3) with Eq. (11) and Eq. (12) we obtain $R_{T O A}(\lambda)$ in the following form:

$$
R_{T O A}(\lambda)=R^{*}(\lambda)+t(\lambda) B(\lambda)\left\{1-\exp \left[-\frac{\left(\alpha(\lambda)+\beta(\lambda) \times R_{T O A}(N I R)\right)}{S(\lambda)}\right]\right\}
$$


where $R_{T O A}(\lambda)$ is top-of-atmosphere reflectance (in the visual domain), $R^{*}(\lambda)$ involves the contribution of the atmosphere to the top-of-atmosphere reflectance (in the visual domain) and reflection of sky light off the water surface (see Eq. (3)); $R_{T O A}(N I R)$ is top-of-atmosphere in the near-IR domain, $\alpha(\lambda)$, $\beta(\lambda)$ - optimized parameters, $B(\lambda)$ - the asymptotic value of $R_{T O A}(\lambda), t(\lambda)$ - diffuse transmittance of the atmosphere, $S P M$ - the concentration of suspended sediments $\left[\mathrm{g} \mathrm{m}^{-3}\right], S(\lambda)$ - the saturation concentration of SPM for a given wavelength $\left[\mathrm{g} \mathrm{m}^{-3}\right]$.

Eq. (13) is mathematically over-determined due to the five unknown parameters involved. It is obvious that this problem cannot be solved analytically. A range of optimization algorithms, such as the quasi-Newton technique, Downhill Simplex, or Levenberg-Marquardt may be deployed to obtain the optimal model parameters by minimizing a predefined "objective function" (Motulsky and Christopulos, 2003; Nash and Sofer, 1996; Nelder and Mead, 1965). In this paper, the Monte Carlo technique was used. The objective function is calculated as a weighted error $(W E)$ to eliminate the possible influence of scatter:
$W E=\sum_{i=1}^{N}\left[\frac{\left(\varepsilon-\varepsilon_{F I T}\right)}{\varepsilon}\right]^{2}$,

where $\varepsilon$ is the observed variable, $\varepsilon_{F I T}$ - the corresponding fitted value, and $N$ denotes the number of points.

The Monte Carlo optimization technique is based on assigning, or "shooting", random numbers to the unknown parameters from a pre-defined interval (constrained boundaries), by which the risk of falling into a local minimum of the objective function is suppressed. As such, the technique requires some educated guessing in assigning initial values of the sought parameters, i.e. the procedure has to be done repeatedly several times until a physically plausible solution is reached and the objective function (weighted error in our case) is minimized.

\section{Description of the study site}

The study site is located in Gabčíkovo Impoundment $\left(48^{\circ} 00^{\prime} \mathrm{N} 17^{\circ} 25^{\prime} \mathrm{E}\right)$, Slovakia, a river-fed reservoir located on the Danube River. Fig. 2 depicts the geographical setting of the study area

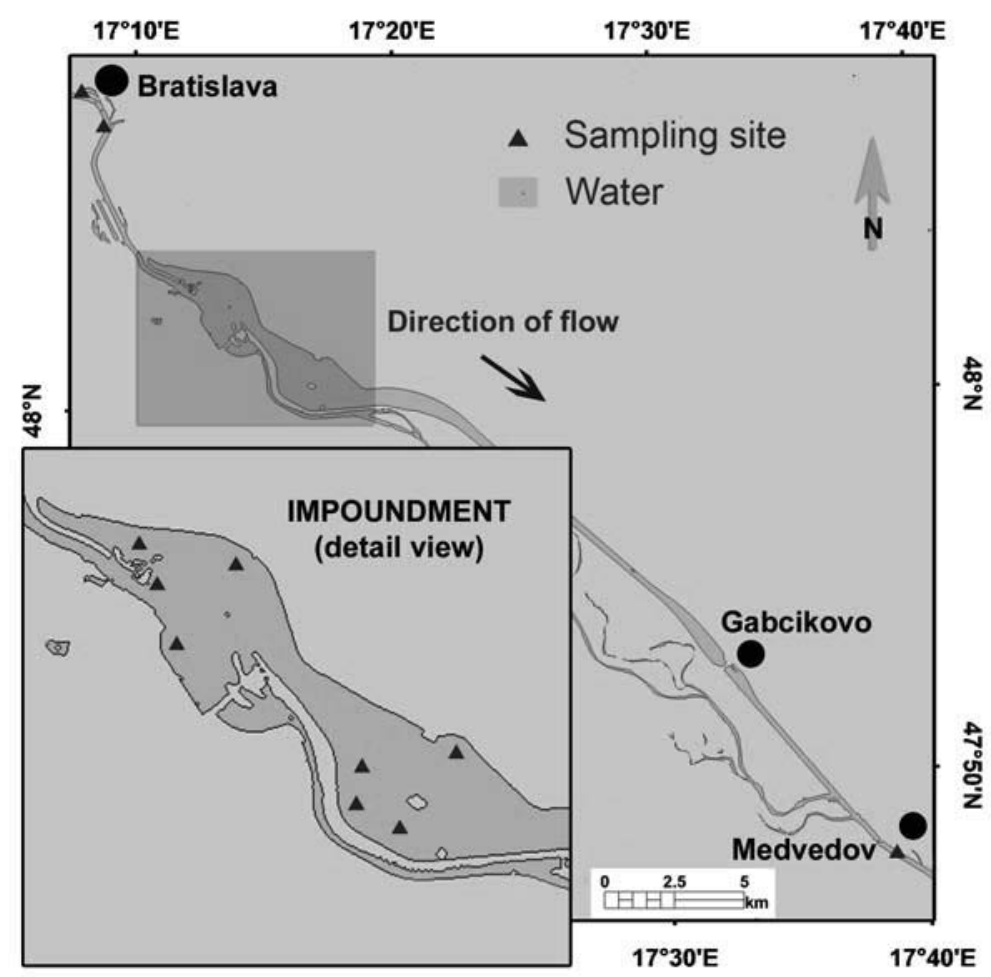

Fig. 2. Study area and the locations of sampling sites. For clarity, the impoundment is shown in an enlarged area in the lower left corner. 
along with the locations of the sampling sites. The drainage area upstream from the study site is $\sim 131,338 \mathrm{~km}^{2}$. The retention volume of the reservoir is $110.8 \times 10^{6} \mathrm{~m}^{3}$. The long-term average discharge at the gauging station located at Bratislava (Fig. 2) is $2058 \mathrm{~m}^{3} \mathrm{~s}^{-1}$ (Pekárová et al., 2008). On the date of the satellite image acquisition (May 14, 2000), the discharge was $3763 \mathrm{~m}^{3} \mathrm{~s}^{-1}$. The crosssectional width of the main channel is approximately 300 meters, with over 2500 meters across the impoundment. Suspended particulate matter in the impoundment are delivered from the upper watershed, including the Alps regions and a smaller tributary - the Morava River joining the Danube a few

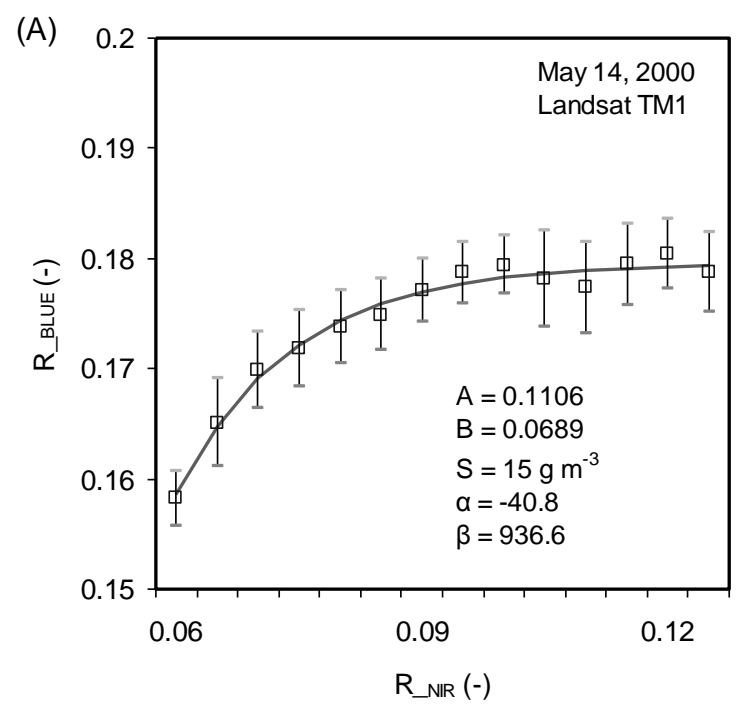

kilometers upstream from the study area. Between 1994 and 2003, the average annual sediment discharge was $3.2 \times 10^{6}$ metric tons per year, with an average concentration of $38.4 \mathrm{~g} \mathrm{~m}^{-3}$. At the entrance of the impoundment, the median grain-size is $\sim 7$ $11 \mu \mathrm{m}$, the particle size fraction $<4 \mu \mathrm{m}$ accounts for $6-16 \%$, the fraction between $4-62 \mu \mathrm{m}$ accounts for $70-90 \%$, and the sand fraction $(>62 \mu \mathrm{m})$ is represented by $4-14 \%$ (Holubová et al., 1998; Lukáč, 2002). Long-term monitoring in this area shows that water column transparency rarely exceeds 1 meter. The depth in the impoundment varies between $\sim 2$ meters near the shoreline, and $\sim 8$ meters in the central section (thalweg) which is
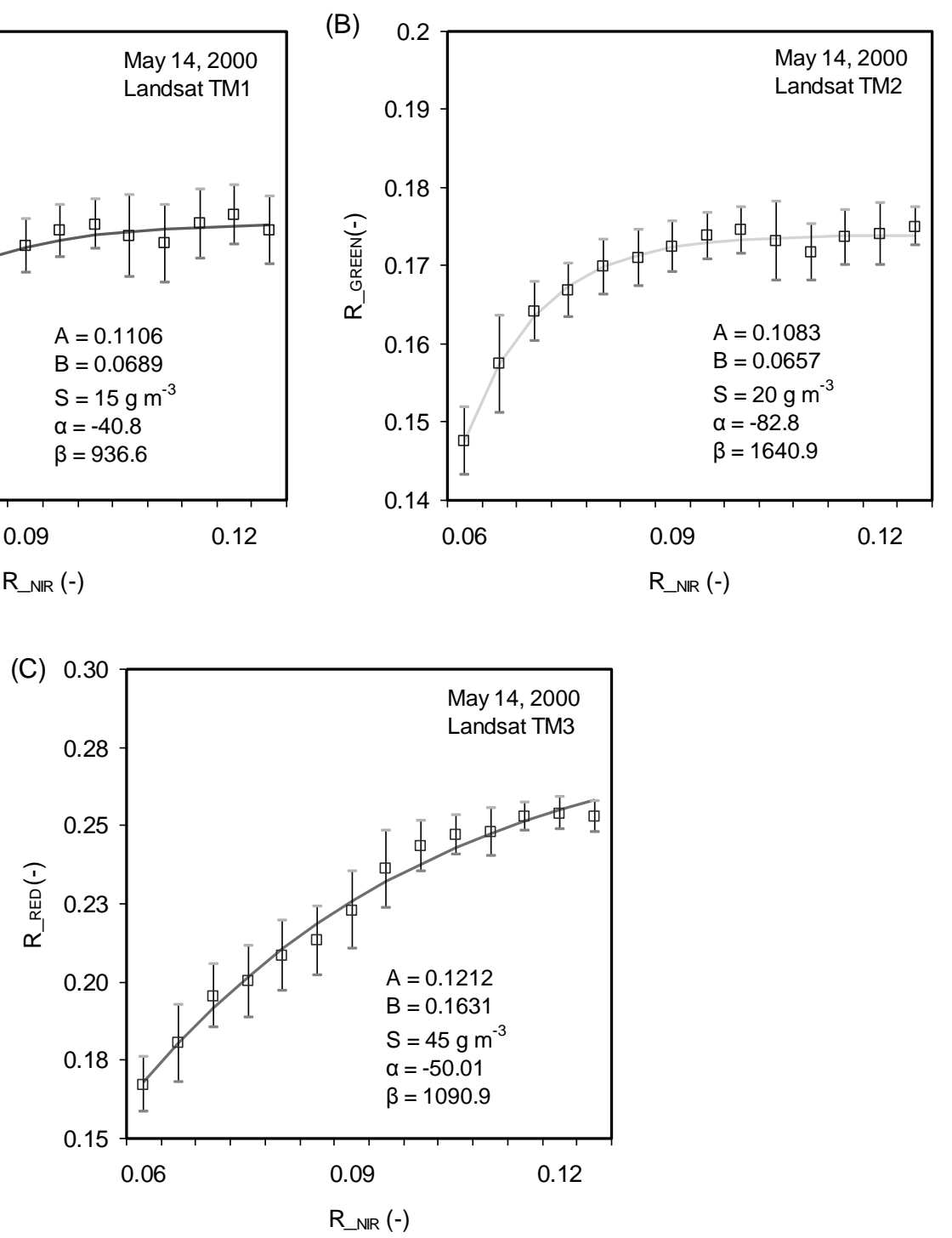

Fig. 3. Response of the total at-sensor radiance in three spectral bands of Landsat ETM+ to increasing SPM. (A) blue band; (B) green band, and (C) red band. Values of the image-extracted top-of-atmosphere reflectance are shown as mean $+/$ - standard deviations for reflectance values from the TM4 band (near-IR). All fitted to Eq. (12) using the weighted error (Eq. (14)) as the objective function. 


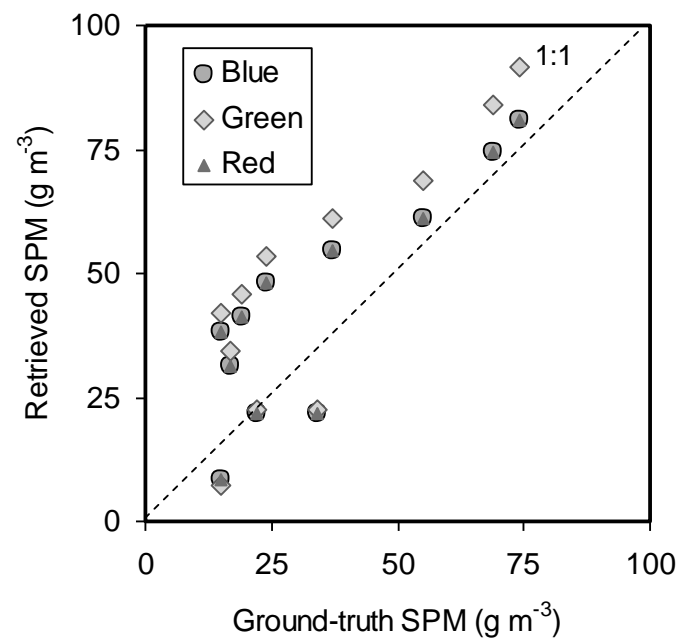

Fig. 4. Comparison of simulated (retrieved) and ground-truth measurements of SPM $\left[\mathrm{g} \mathrm{m}^{-3}\right]$ for the date of the satellite image acquisition (May 14, 2000). The near-IR band was calibrated by Eq. (18), using $\alpha$ (increment) and $\beta$ (slope) obtained from optimization of Eq. (13) for the three visual domains (Tab. 2). In the case of the blue band, the mean error between measured and retrieved SPM $=10.5 \mathrm{~g} \mathrm{~m}^{-3}\left(17.3\right.$ and $12.6 \mathrm{~g} \mathrm{~m}^{-3}$ for the green and red bands, respectively).

used for navigation. Fig. 2 shows the location of the sampling sites that have been carefully chosen to represent a variety of hydraulic conditions in the feeding channel and the impoundment itself $(\mathrm{N}=$ =11). SPM concentrations were measured in compliance with the official measuring national sampling protocols, i.e. depth-integrated samples of water are collected by gradually lowering a sampler with a 1-liter polyethylene bottle attached. The filtration of water samples was performed on preweighted 0.45 -micron membrane filters. The concentration of SPM was determined gravimetrically after combustion at $105^{\circ} \mathrm{C}$.

\section{Results and discussion}

A high resolution multispectral image (Landsat ETM+) was used to demonstrate the applicability of the presented technique. The choice to use Landsat ETM+ was based on making a tradeoff between the spatial and spectral resolution of commercially available satellite sensors. Considering the dimensions of the impoundment (2500 meters, Fig. 2) and the average cross-sectional width of the river channel ( 300 meters), Landsat ETM+ provides a sufficient spatial-resolution ( 30 by 30 meters per pixel). Because the width of the river channel in this section is about ten times the Landsat spatial reso- lution; collecting pixels close to the channel centerline was considered sufficient to prevent contamination of the extracted pixels by the adjacent landscape. The image used in this study was acquired on May, 14, 2000 (a cloud-free scene). Field inspections in the study area revealed that various species of vascular aquatic plants grow near the shoreline. In order to avoid an accidental contamination of the extracted pixels by the macrophytes, a buffer zone (based on available bathymetric measurements) was created to exclude such potentially contaminated pixels. Water-masked images were used to extract some 2000 pixels from four spectral bands (blue TM1, green TM2, red TM3, and nearIR TM4) which were recalculated to top-of atmosphere reflectances $R_{T O A}(\lambda)$ according to Eq. (1) and Eq. (2).

Eq. (13) was optimized for its parameters $\left(\mathrm{R}^{*}(\lambda)\right.$, $t(\lambda) \mathrm{B}(\lambda), \alpha(\lambda)$, and $\beta(\lambda))$ by means of the quasiNewton technique. Weighted error (Eq. (14)) was used as the objective function. In order to start an optimizing procedure, it is useful to set constraints and the initial values of the unknown parameters to make sure that the optimized parameters will converge to physically plausible values. A minimum SPM concentration of $5 \mathrm{~g} \mathrm{~m}^{-3}$ was used as a constraint to the model. Shiebie et al. (1992) concluded a study in Chicot Lake, Arkansas, USA, to test Eq. (13) in field conditions using data from Landsat TM. The authors concluded that in the spectral domain of $\sim 400-500 \mathrm{~nm}$ the saturation concentration was $26.3 \mathrm{~g} \mathrm{~m}^{-3}$; whereas at longer wavelengths the saturation effect shifted toward higher concentrations: $56.5 \mathrm{~g} \mathrm{~m}^{-3}$ for $500-600 \mathrm{~nm}$; and $88.8 \mathrm{~g} \mathrm{~m}^{-3}$ for $600-700 \mathrm{~nm}$, respectively. It can be argued that these values are not transferable between different bodies of water; nevertheless, these values provide a good starting point for our optimization problem (initial values for optimization). The optimized parameters of Eq. (13) are listed in Tab. 1. The lowest weighted error was achieved for the green Landsat band (Tab. 1).

To gain a sense of how well the simulated concentrations of suspended sediments correspond to in-situ measurements, a comparison was made between image-derived (5-by-5 pixel windows) and ground measurements (Fig. 4). The average deviation of the retrieved concentrations of SPM from in situ measurements was $\sim 10.5 \mathrm{~g} \mathrm{~m}^{-3}$, which is within the commonly reported error obtained by other investigators. For example Doxaran et al. (2002a) investigated a highly turbid estuary with SPM con- 
centrations up to $2000 \mathrm{~g} \mathrm{~m}^{-3}$ for which they estimated the accuracy of their model as $\pm 35 \%$. Considering the range of the measured range of SPM concentrations in our study, the accuracy of our approach is optimistic. It would be an interesting avenue for future research to apply the presented technique to multiple multispectral images, possibly covering a broader range of SPM concentrations and different water bodies.

T a b 1 e 1. Parameters obtained from optimization of Eq. (13) $[A(\lambda), t(\lambda) B(\lambda), S(\lambda), \alpha(\lambda)$, and $\beta(\lambda)]$. Weighted error was calculated according to Eq. (14).

\begin{tabular}{ccccccc}
\hline Spectral band & $R_{\text {ATM }}(\lambda)$ & $t(\lambda) B(\lambda)$ & $S(\lambda)$ & $\alpha(\lambda)$ & $\beta(\lambda)$ & $\begin{array}{c}\text { Weighted } \\
\text { error }\end{array}$ \\
\hline Blue $(450-520 \mathrm{~nm})$ & 0.1106 & 0.0689 & 15 & -40.8 & 936.6 & 0.000423 \\
Green $(560-610 \mathrm{~nm})$ & 0.1083 & 0.0656 & 20 & -82.8 & 1641.2 & 0.000287 \\
Red $(630-690 \mathrm{~nm})$ & 0.1212 & 0.1631 & 45 & -50.0 & 1090.9 & 0.01325 \\
\hline
\end{tabular}

\section{Conclusions}

The main motivation of this paper was to present a novel approach in terms of how remotely sensed data can be used for estimating concentrations of suspended matter in inland waters without ground measurements. The results presented demonstrate the strong potential of the asymptotic relationship between elevated SPM and reflectance and linear response of reflectance to SPM in the near-IR portion of the spectrum. The effect of signal saturation in the visible domain of wavelengths (e.g. 450$-700 \mathrm{~nm}$ ) at high SPM levels is often deemed undesired; however, we have shown that it can become beneficial when traditional in situ measurements are not available. We have also shown that the reflectance in the near-IR domain can be directly used for calculating SPM. The success of the selfcalibrating technique is guarantied only if SPM is present in a broad range of concentrations in order to identify saturation concentration of SPM. This assumption is essential in order to properly optimize the exponential relationship between SPM and reflectance. Another strength of the presented technique is that no correction for atmospheric effects is needed because of the semi-empirical nature of the approach (Eq. (13)) and assuming that atmospheric conditions over the investigated area and the inherent optical properties of water constituents are spatially homogeneous.

Acknowledgment. The authors wish to express their gratitude to APVV (No. 0448/07), MVTS (No. PI5126), and VEGA 0096 and 2/0123/11, for providing necessary funding.

\section{REFERENCES}

BABAN S. M. J., 1995: The use of Landsat imagery to map fluvial sediment discharge into coastal waters. Marine Geol., 123, 263-270.

BABIN M., MOREL A., FOURNIER-SICRE V., FELL F., STRAMSKI D., 2003: Light scattering properties of marine particles in coastal and open ocean waters as related to the particle mass concentration. Limnol. and Oceanography, 48, 2, 843-859.

BINDING C. E., BOWERS D. G., MITCHELSON-JACOB E. G., 2005: Estimating suspended sediment concentrations from ocean coour measurements in moderately turbid waters; the impact of variable particle scattering properties. Remote Sensing of Environment, 94, 373-383.

BOWERS D. G., BINDING C. E., 2006: The optical properties of mineral suspended particles: A review and synthesis. Esturine Coastal and Shelf Science, 67, 219-230.

BOWERS D. G., BRAITHWAITE K. M., NIMMO-SMITH W. A. M., GRAHAM G. W., 2009: Light scattering by particles suspended in the sea: The role of particle size and density. Continental Shelf Research, 29, 1748-1755.

BRICAURD A., MOREL A., PRIEUR L., 1981: Absorption by dissolved organic matter of the sea (yellow substance) in the UV and visible domains. Limnol. Oceanogr., 26, 1, 43-53.

BUKATA R., JEROME J. H., BORSTAD G. A., BROWN L. N., GOWER J. F. R., 2004: Mitigating the impact of transspectral processes on multivariate retrieval of water quality parameters from case 2 waters. Can. J. Remote Sensing, 30, $8-16$.

BUKATA R. P., JEROME J. H., KONDRATYEV K. Y., KOTYKHOV A. A., 1997: Modelling the Radiometric Color of Inland Waters: Implications to a) Remote Sensing and B) Limnological Color Scales. J. Great Lakes Research., 23, 254-269.

CHAKRAPANI G. J., 2005: Factors controlling variations in river sediment loads. Current Sci., 88, 569-575.

CHRISTIAN, D., SHENG, Y., 2003: Relative influence of various water quality parameters on light attenuation in Indian River Lagoon. Estuarine, Coastal and Shelf Science, 57, 961-971.

DECHO A. W., KAWAGUCHI T., ALLISON M., A., et al., 2003: Sediment properties influencing upwelling spectral 
reflectance signatures: The "biofilm gel effect". Limnol. Oceanogr., 48, 431-443.

DEKKER A.G., VOS R. J., PETERS S. W. M., 2001: Comparison of remote sensing data, model results and in situ data for total suspended sediment matter (TSM) in the southern Frisian lakes. Science of the Total Environment., 268, 197$-214$.

DOXARAN D., FROINDENFOND J. M., LAVENDER S., CASTAING P., 2002a): Spectral signature of highly turbid waters: Application with SPOT data to quantify suspended particulate matter concentrations. Remote Sensing of Environment., 81, 149-161.

DOXARAN D., FROINDENFOND J. M., CASTAING P. A., 2002b): A reflectance based ratio used to estimate suspended matter concentrations in sediment dominated coastal waters. Int. J. Remote Sens., 23, 5079-5085.

DOXARAN D., CHERUKURU R. C., LAVENDER S. J., 2004: Estimation of surface reflection effects on upwelling radiance field measurements in turbid waters. J. Optics: A pure and Applied Optics., 6, 690-697.

DOXARAN D., FROINDENFOND J. M., CASTAING P., BABIN M., 2009: Dynamics of the turbidity maximum zone in a macrotidal estuary (the Gironde, France): Observations from field and MODIS satellite data. Estuarine, Coastal and Shelf Science., 81, 321-332.

GALLEGOS C., 2001: Calculating optical water targets to restore and protect submersed aquatic vegetation: Overcomming problems in partitioning the diffuse attenuation coefficient for photosynthetically active radiation. Estuaries, 24, 3, 381-397.

GIARDINO C., PEPE M., BRIVIO P., GHEZZI P., ZILIONI E., 2001: Detecting chlorophyll, Sechci disk depth and surface temperature in sub-alpine lake usinh Landsat imagery. Science of the Total Environment, 268, 19-29.

GORDON H. R., BROWN O. B., and JACOBS M. M., 1975 Computed relations between the inherent and apparent optical properties of a flat homogeneous ocean. Appl. Opt., 14, 417-427.

GORDON H. R. and WANG M., 1994: Influence of oceanic whitecaps on atmospheric correction of ocean-color sensors. Appl. Opt., 33, 7754-7763.

HAN L., RUNDQUIST D.C., 1996: Spectral characterization of suspended sediment generated from two texture classes of clay soil. Int. J. Remote Sensing., 17, 643-649.

HOLUBOVÁ K., SZOLGAY J., LUKÁČ M., CAPEKOVÁ Z. et al., 1998: The regime of suspended load and bedload in the vecinity of the capital city (Bratislava) in response to the altered runoff regime. (In Slovak.) Final Report of the Project No. VTP 95/5145/622, Water Reasearch Institute, Bratislava, Slovakia.

IOCCG, 2000: Remote Sensing of Ocean Colour in Coastal, and Other Optically-Complex Waters. Sathyendranath, S (ed.), Reports of the International Ocean-Colour Coordinating, Group, No. 3, IOCCG, Dartmouth, Canada.

JERLOV N G., 1968: Optical oceanography. Elsevier

KARBASSI A, MOATTAR B., 2006: Origin and chemical partitioning of heavy metals in riverbed sediments. Int. J. Environ. Sci. Technol., 3, 35-42.

KELBLE C. R., ORTNER P. B., HITCHOCK G. L., BOYER J. N., 2005: Attenuation of photosynthetically available radiation (PAR) in Florida Bay: potential for light limitation of primary producers. Estuaries, 28, 560-571.

KIRK J. T. O.: 1976: Yellow substance (Gelbstoff) and its contribution to the attenuation of photosynthetically active radiation in some inland and coastal south-eastern Australian waters. Aust. J. Mar. Freshwater Res., 27, 61-71.

KLAVER G., van OS B., NEGREL P., PETELET-GIRAUD E., 2007: Influence of hydropower dams on the composition of the suspended and river bank sediments in the Danube. Environmental Pollution. 148, 718-728.

KLEMAS V., OTLEY M., PHILPOT W., WETHE C., ROGERS R., SHAH N., 1974: Correlation of coastal water turbidity and current circulation with ERTS-1 and Skylab imagery. Proc. 9th int. symp. remote sensing of environment. Res. Inst. Michigan, Ann Arbour, Michigan; pp. 1289-1317.

KLOIBER S., BREZONIK P., OLMANSON L., BAUER M., 2002: A procedure for regional lake water quality assessment using Landsat multispectral data. Remote Sensing of Environment, 82, 38-47.

LAHET F., OUILLON S., FORGET P., 2000: A three component model of ocean colour and its application in the Ebro River mouth area. Remote Sensing of Environment., 72, 181-190.

LeCROY S. R., 1982: Determination of Turbidity Patterns in Lake Chikot from Landsat MMS imagery. NASA Contractor Report 165870, Langley Research Center, Hampton, VA, USA. 1982.

LIU YANSUI, ISLAM M. D., GAO J., 2003: Quantification of shallow water quality parameters by means of remote sensing. Progress in Physical Geography, 27, 24-43.

LUKÁC M., 2002: Mass balance of the suspended load in the Danube River between Bratislava-Medvedov, Slovakia. (In Slovak.) In: the Proceedings of the conference "10 Years of the operation of the Gabčíkovo Water Project". October 25, 2002, Bratislava, Slovakia. 55-58.

MÉLIN F., ZIBORDI G., DJAVIDNIA S., 2009: Merged series of normalized water leaving radiances obtained from satellite missions for the Mediterranean Sea. Advances in Space Res., 43, 423-437.

MILLIMAN J.D., 1991: Flux and fate of fluvial sediments and water in coastal seas. In Ocean Margin Processes in Global Change (eds Mantoura R.F.C., Martin J., M., Wollast R.), John Wiley.

MISHRA A. K., 2004: Retrieval of suspended sediment concentrations in the estuarine waters using IRS-1C WiFS data. Int. J. Appl. Earth Observat. and Geoinformat., 6, 83-95.

MOBLEY C. D. and STRAMSKI D., 1997: Effects of microbial particles on oceanic optics: Methodology for radiative transfer modeling and example simulations. Limnol. Oceanogr., 42, 3, 550-560.

MOREL A. and GENTILI B., 1996: Diffuse reflectance of oceanic waters. II. Implication of bidirectionality for the remote-sensing problem. Appl. Opt. 35, 4850-4861.

MOREL A., PIEUR L., 1977: Analysis of variations in ocean colour. Limnol. Oceanogr., 22, 4, 709-722.

NASH S.G., SOFER A., 1996: Linear and Nonlinear Programming. McGraw-Hill New York, pp. 409-423.

MOORE G. K., 1980: Satellite remote sensing of water turbidity. Hydrological Sciences - Bulletin - des Sciences Hydrologiques, 25, 4.

MOTULSKY H. J., CHRISTOPULOS A., 2003: Fitting models to biological data using linear and nonlinear regression. A practical guide to curve fitting. GraphPad Software Inc., San Diego CA, www.graphpad.com.

NASA Landsat Handbook: http://landsathandbook.gsfc.nasa. gov/handbook.html 
NELDER, J. A., MEAD, R., 1965: A simplex method for function minimization. Comput. J., 7, 308-313.

OUILLON S., DOUILLET P., PETRENKO A., NEVEUX J., DUPOUY C., FROIDEFOND J. M., ANDRÉFOUËT S., MUÑOZ-CARAVACA A., 2008: Optical Algorithms at Satellite Wavelengths for Total Suspended Matter in Tropical Coastal Waters. Sensors., 8, 4165-4185.

PEKÁROVÁ P., ONDERKA M., PEKÁR P., MIKLÁNEK P., HALMOVÁ D., ŠKODA P., BAČOVÁ-MITKOVÁ V., 2008: Hydrologic scenarios of the Danube River at Bratislava. Slovak Committee for Hydrology, UNESCO, KeyPublishing, ISBN 978-80-87071-51-9, pp. 11.

PETZOLD T. J., 1972: Volume scattering coefficients for selected oceanic waters. In: Tyler, Light in the Sea, Dowden, Hutchinson and Ross, pp 155-174.

POPE R. M., FRY E. S., 1997: Absorption spectrum (380-700 $\mathrm{nm})$ of pure water. II. Integrating cavity measurements. Appl. Opt. 36, 8710-8723.

PREISENDORFER R. W., 1961: Application of radiative transfer theory to light measurements in the sea. Int. Union Geod. Geophys. Monogr., p. 11-30.

RITCHIE J. C., SCHIEBE F. R., 1985: Monitoring Suspended Sediments with Remote Sensing Techniques. Hydrologic Applications of Space Technology, Proceedings of the Cocoa Beach Workshop, Florida, August 1985. IAHS Publ. No. 160, 223-243.

RUDDICK K. G., CAUWER V. D., PARK YOUNG-JE, 2006: Seaborne measurements of near infrared water-leaving reflectance: The similarity spectrum for turbid waters. Limnol. Oceanogr., 51, 2, 1167-1179. 2006.

SANJAY K. J., PRATAP S., 2002: Assessment of sedimentation in Bhakra Reservoir in the western Himalayan region using remotely sensed data. Hydrological Sciences-des Sciences Hydrologiques, 47, 203-212.

SCHIEBE F. R., HARRINGTON Jr., RITCHIE J. C., 1992: Remote sensing of suspended sediments: the Lake Chicot, Arkansas project, Int. J. Remote Sensing, 13, 8, 1487-1509.

SCHALLES J. F., RUNDQUIST D. C., SCHIEBE F. R., 2001: The influence of suspended clays on phytoplankton reflec- tance signatures and the remote estimation of chlorophyll. Verh. Internat. Verein. Limnol., 27, 3619-3625.

SMITH R. C., BAKER K. S., 1981: Optical properties of the clearest natural waters. Appl. Opt., 20, 177-184.

SYVITSKI J. P. M., MOREHEAD M., NICHOLSON M., 1998: A climate driven hydrologic transport model for predicting discharge and sediment to lakes and oceans. Comp. Geosci., 24, 51-68.

TOLK B. L., HAN L., RUNDQUIST D. C., 2000: The impact of bottom brightness on spectral reflectance of suspended sediments. Int. J. Remote Sensing, 21, 2259-2268.

VIERS J., DUPRÉ B., GAILLARDET J., 2009: Chemical composition of suspended sediments in World Rivers: New insights from a new database. Science of the Total Environment, 407, 853-868.

WARRICK J. A., MERTES L. A. K., SIEGEL D. A., MACKENZIE C., 2004: Estimating suspended sediment concentrations in turbid coastal waters of the Santa Barbara Channel with SeaWiFSINT. J. Remote Sensing. 25, 1995-2002.

WALLING D.E., 2006: Human impact on land-ocean sediment transfer by the world's rivers. Geomorphology, 79, 192$-216$.

WANG J., LU X., ZHOU Y., 2007: Retrieval of suspended sediment concentrations in the turbid water of the Upper Yangtze River using Landsat ETM+. Chinese Sci. Bull., Springer, 52, supp. II, 273-280.

WHITLOCK C. H., WITTE W. G., TALANY T. A., MORRIS W. D., USRY J. W. and POOLE L. R., 1981: Research for reliable quantification of water sediments concentration from multispectral sensor remote sensing data. USDA/NASA AgRISTARS Report CP-Z1-04078 (JSC17134).

ZORAN M., ANDERSON E., 2006: The use of multi-temporal and multispectral satellite data for change detection analysis of the Romanian Black Sea coastal zone. J. Optoelectronics and Advanced Materials, 8, 252-256.

Received 24 March 2011 Accepted 19 October 2011 